Review Article

\title{
Studies on Quaternary Glaciations in India During 2010-2016
}

\author{
MILAP CHAND SHARMA* and PRITAM CHAND \\ Centre for the Study of Regional Development (CSRD), School of Social Science (SSS), Jawaharlal \\ Nehru University (JNU), New Delhi 110 067, India
}

(Received on 21 June 2016; Accepted on 14 July 2016)

\begin{abstract}
In the recent years, number of studies were carried out to define the timing and extent of Quaternary glaciation throughout the Himalayan region. Such studies have helped to understand the past climate changes and further develop predictive futuristic models. There have been 22 research studies that were carried out during the past six years (2010-2016) with equal contribution from Indian researcher and their international counterparts in terms of research output. Most of these studies have focused on the north-western Himalaya, with only a few studies being carried out in the eastern part. Recently published new glacial succession chronology (Terrestrial Cosmogenic Nuclide $\left({ }^{10} \mathrm{Be}\right.$ TCN), Optically Stimulated Luminescence (OSL), Electron Spin Resonance (ESR) and Radiocarbon $\left({ }^{14} \mathrm{C}\right)$ ) in these studies provide a synoptic picture of glacial episode for most the Himalayan regions. Major glacial advances occurred during the Last glacial stage and early Holocene, with minor fluctuations during the mid-Holocene. However, recent study suggests contrary to the earlier suggestions that a reasonably large valley glacier expansion occurred during the global Last Glacial Maxmium (LGM), likely in response to global variations in temperature.
\end{abstract}

Keywords: Quaternary Glaciation; Himalaya; Late Glacial; Last Glacial Maxmium (LGM) and Holocene

\section{Introduction}

The Himalayan region altered large-scale climate systems including the Asian monsoon and considerably influenced the regional and global atmospheric circulation that may have played a key role in the onset of Quaternary glaciation (Molnar and England, 1990; Ruddiman and Kutzbach, 1991; Prell and Kutzbach, 1992; Raymo and Ruddiman, 1992; Benn and Owen, 1998; Owen et al., 2002). Information on the geographic extent and magnitude of Quaternary glaciations in this largest glaciated area outside the polar region is important for understanding the climatic, erosional, and tectonic evolution of this giant orogenic system (Brozovic et al., 1997; Zeitler et al., 2001; Norton et al., 2010; Willett, 2010). Practically in the context of contemporary global warming, climate variability, and associated societal impacts and for a better assessment of regional and global forcing factors for future glacier behavior, it is important to characterize and quantify past glacial changes (Owen, 2009; Scherler, 2010).There is a growing number of chronologic data and studies in recent years, yet there is no general consensus concerning the timing, extent, and climatic forcing of glaciations in the Himalayan region (Gillespie and Molnar, 1995; Owen et al., 2008; Scherler et al., 2010; Owen and Dortch, 2014). This region is fed by two dominant climate systems viz. the Indian summer monsoon (ISM) and the mid-latitude westerlies. The influence of these weather systems varies spatially so much that most of the southern and eastern part of the Himalaya experiences a pronounced summer precipitation which sharply declines northward across the Himalaya. The mid-latitude westerlies are responsible for a winter precipitation maximum at the extreme west of the Himalaya, Trans-Himalaya and Tibet (Benn and Owen 1998; Yang et al., 2008). Benn and Owen (1998) hypothesized that the relative role of these two dominant climate systems varied significantly throughout the Quaternary, resulting in asynchronous glaciation across the Himalaya region. In recent years, numerous researchers have undertaken detailed

\footnotetext{
*Author for Correspondence: E-mail:milap@jnu.ac.in
} 
studies of the region's Quaternary glaciation supported by better approachability, latest remote sensing techniques and numerical dating that resulted number of publications and allow to provide an inclusive overview on Quaternary glaciation of the Himalayan region. With this consideration, the study has an objective to synthesis recent studies carried out since last six years i.e., January 2010 to April, 2016 on Himalayan Quaternary glaciation, to provide an exhaustive review on Quaternary Glaciation for Himalaya region and to examine the role of climate and other forcing factors on Quaternary glaciation and further to understand the nature of climate change in the region.

\section{Methods}

In the past six years, number of attempts have been made to generate numerical ages on the moraine successions. Thus, to know the status of research on Himalayan Quaternary glaciation, bibliometric indicators and evidence were analysed to allow the recent research in this area and for this purpose we used largest database of peer-reviewed literature from following websites e.g. Scopus (https:// www.scopus.com/) and Web of Science databases (http://thomsonreuters.com/en/products-services/ scholarly-scientific-research/scholarly-search-anddiscovery/web-of-science.html). We conducted our study using simple and advance search option available in the above mentioned websites. We restricted attention to the past 6 year period i.e. 2010 January 2016 April. For search strategy, we used 'Glaciation' as a keyword and further include the 'Himalaya' and 'Glacial' as an additional keywords in Boolean operation mode of search option in the title, topic and publication name fields for all above mentioned web portal (webpage accessed during the period 1 May to 15 May 2016). Besides, we update here the results published in recent publications started from 2010 to till April 2016 and incorporating inferences from recent reviews provided by Ali and Juyal (2013), Dortch et al. (2013); Murari et al. (2014); Owen and Dortch (2014) by combining more than $>1700{ }^{10} \mathrm{Be}$ dates. Instead of individual numerical ages of these studies, we focus on the search for certain patterns in glacier variations during the Quaternary period and their potential drivers. We direct readers to the original publications for the details and individual dates of glacier advances.

\section{Studies on Himalayan Quaternary Glaciations (2010-2016)}

There are 22 articles that have been published on Himalayan Quaternary glaciation during this period that includes four review articles. These articles have collected 217 citations. Most of studies were concentrated in the north western Himalaya and mostly focus in Uttarakhand and Jammu and Kashmir (J\&K) Himalaya region (Fig. 1). The Nepal and eastern Himalaya neglected in terms of Quaternary Glaciation research except three studies were found from these regions including a study from eastern Himalaya syntax (Fig. 1). Following the significant developments in OSL and TCN surface exposure dating during the 1990s and early 2000s, respectively, all studies applied either of the techniques/methods and sharing equal percentage i.e. TCN (50\%) and OSL $(50 \%)$ with few studies incorporated both of technique including the ${ }^{14} \mathrm{C}$. However, TCN dates (>250) available more in number to the Himalayan glacial successions than OSL dates $(>40)$ with few ${ }^{14} \mathrm{C}$ dates ( $\sim 6$ Besides, another potentially important technique, ESR dating has been undertaken in the eastern Himalayan syntaxes area. Interestingly, most of the OSL dating based studies have been carried out by the Indian scientists owing to laid-back accessibility of OSL facilities in comparison to TCN facilities which is in initial stage in the country. Although, the contribution of Indian scientists is almost same in terms of sharing the percentage in Himalaya Quaternary glaciation studies. It shows steady growth in scientific output in Himalayan Quaternary glaciation studies from India counterpart during the last six years. Developing the TCN dating facilities, enhancing the existing OSL dating facilities in the country with logistical, accessibility and financial supports can further increase the number of contribution on Himalayan Quaternary glaciation studies form Indian counterpart. The age (TCN, OSL, and ESR) clusters or distributions for the Himalaya are presented graphically in Fig. 2. It allows us to examine reasonably clustered or spread/distribution of glacial expansion ages in the Himalaya. Moreover, the greatest challenge is interpreting the broad spread of ages. Figure 2 demonstrate a decrease in sample frequency with increasing age. This is essentially a function of preservation, with younger landforms being better preserved, more common, less difficult to date and were more active that might have destroyed the 


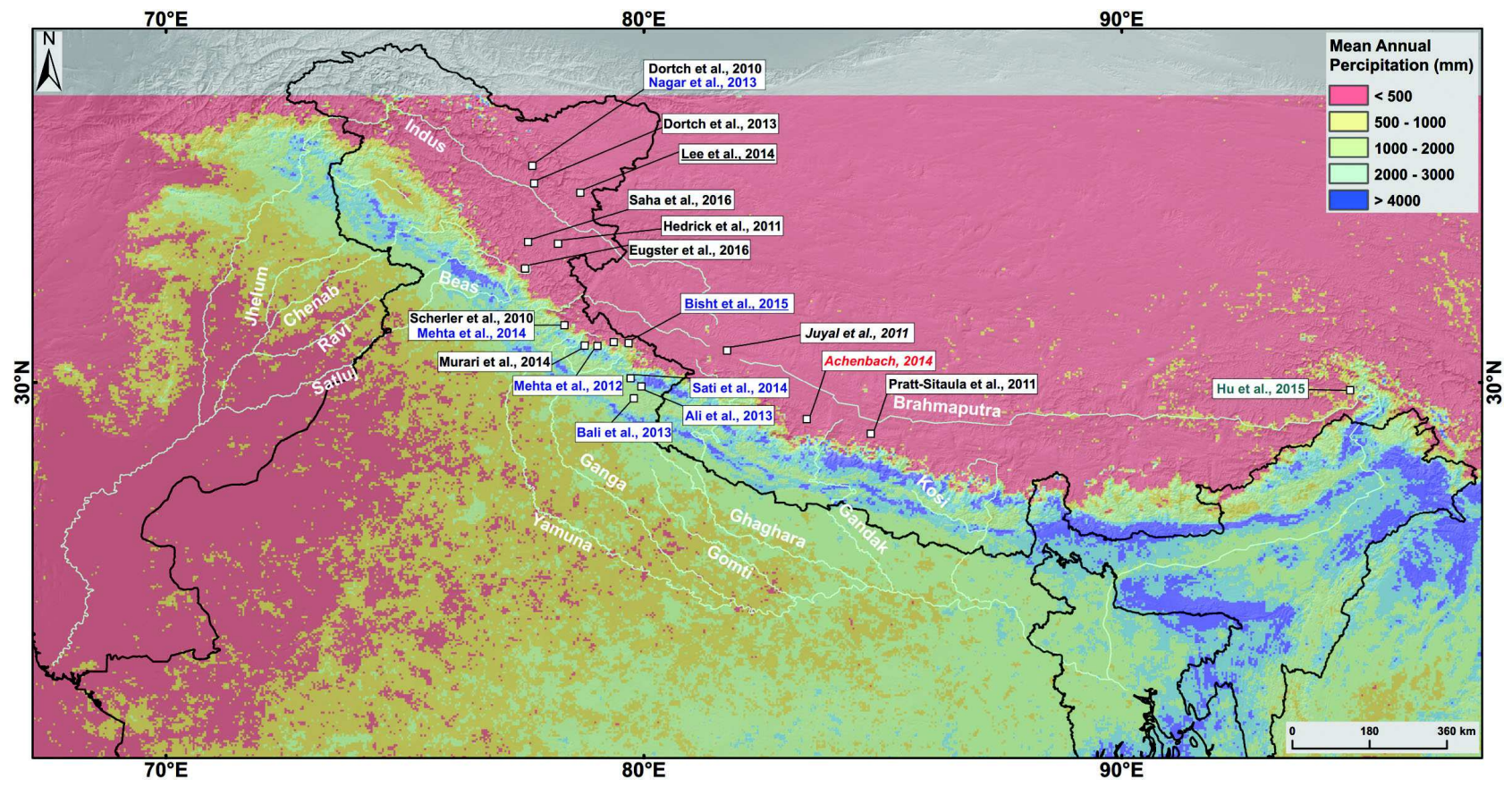

Fig. 1: SRTM Digital Elevation Model (DEM) showing area of studies carried out during the last six years (2010-2016) in the Himalayan region and discussed in detail in this paper. TRMM Precipitation data draped over the SRTM DEM with $30 \%$ opacity showing the trend of precipitation across the Himalayan region (TRMM data source : Bookhagen and Burbank 2006). Note black, blue, red and grey marked text shows studies used TCN, OSL, ${ }^{14} \mathrm{C}$ and ESR dating techniques, respectively and italic black text shows studies in descriptive in nature and not provided chronology.

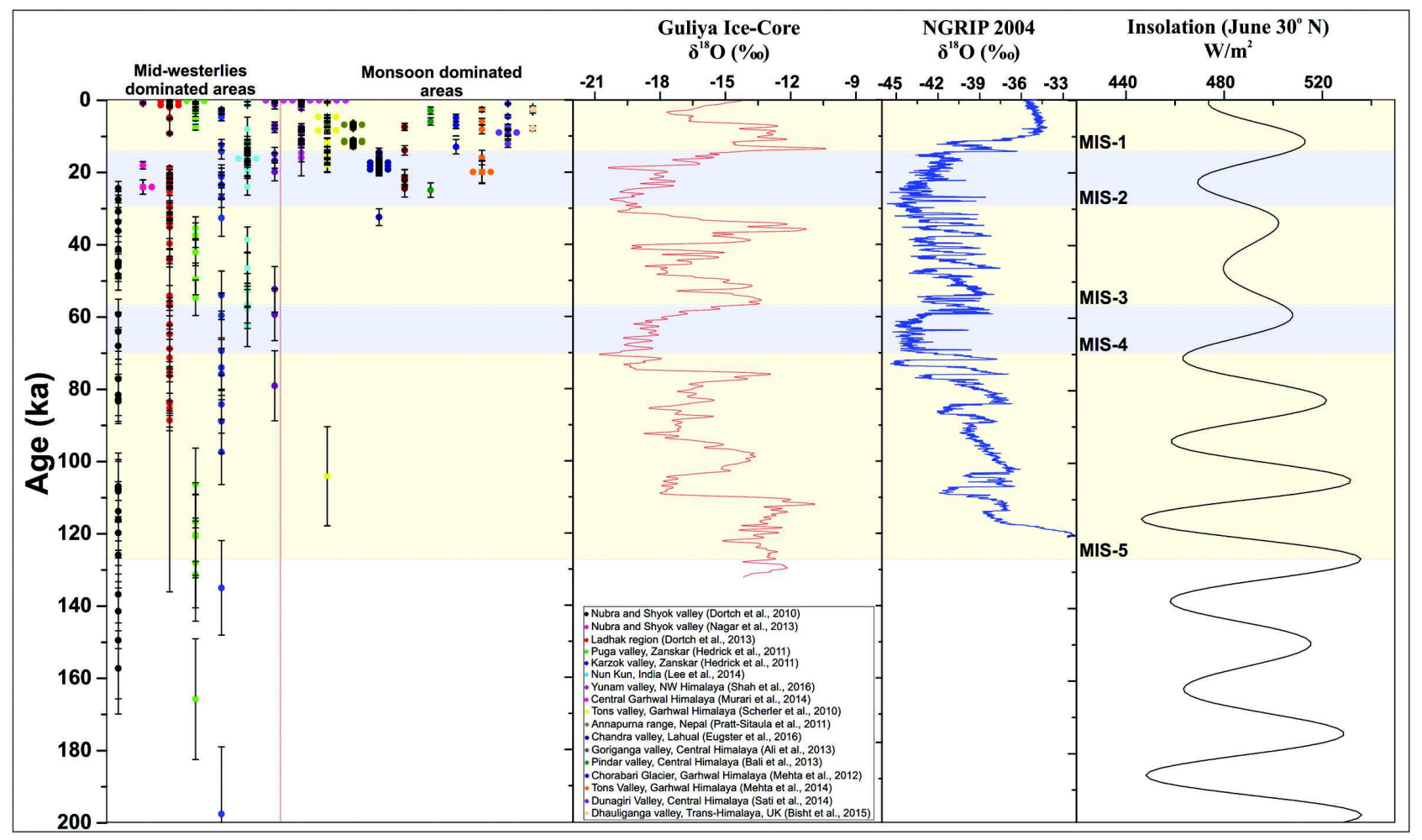

Fig. 2: Age distribution of the all complied ages ( $<200 \mathrm{ka})$ from recent studies (2010-2016) across the Himalayan region and its comparison with the paleo-climate proxy records of the Guliya ice core record (Thompson et al. 1997), NGRIP $\delta^{18} \mathrm{O}$ curve (Andersen et al. 2004) and the simulated $30^{\circ} \mathrm{N}$ insolation (Leuschner and Sirocko 2003) 
evidence of early glaciations. The age distribution have been sorted into two climatic topographic regions semiarid western Himalaya dominated by the mid-latitude westerlies and monsoon-influenced region of Himalaya as same grouped by Dortch et al. (2013), Murari et al. (2014) to maintain consistency in review and discussed in details below.

\section{Semi-arid Western Himalayan Region}

There are seven studies has been carried out for the Semi-arid region during last six years (2010-2016). For instance, Dortch et al. (2010) has been identified three glacial stages viz., Deshkit-1, Deshkit-2 and Deshkit-3 and were dated to $\sim 45 \mathrm{ka}, \sim 81 \mathrm{ka}$ and $\sim 144$ ka respectively, in the mid-westerlies dominated Nubra-Shyok valley in the Karakoram ranges. They suggested that Deshkit-1 and 2 glacial stages seem to be synchronous with regions influenced by monsoon precipitation during MIS-3 and MIS-5/6 transition. However, Nagar et al. (2013) based on OSL chronology suggested that the Nubra valley was extensively glaciated during the LGM and attributes it to the enhanced moisture contribution from the midlatitude westerlies. In addition, recent studies by Dortch et al. (2013) based on exposure dates identified five new glacial stages for the Ladakh Range viz., the Ladakh-4 glacial stage at $81 \pm 20 \mathrm{ka}$; the Ladakh-3 glacial stage (undated); the Ladakh-2glacial stage at $22 \pm 3 \mathrm{ka}$; the Ladakh-1 glacial stage (undated); and the Ladakh Cirque glacial stage at $1.8 \pm 0.4 \mathrm{ka}$. Besides, three local glacial stages are defined for the Pangong Range, which include: the Pangong-2 glacial stage at $85 \pm 15 \mathrm{ka}$; the Pangong-1 glacial stage at 40 $\pm 3 \mathrm{ka}$; and the Pangong Cirque glacial stage at $0.4 \pm$ $0.3 \mathrm{ka}$. These authors have further developed the first regional framework of glaciation by combined new and previously reported chronology across the dryland regions of the Greater Himalaya, Trans-Himalaya, Pamir and Tian-Shan at the western end of the Himalayan-Tibetan orogen. Accordingly suggested that regional glacial stages older than 21 ka are broadly correlated with strong monsoons whereas stages that are 21 ka or younger, correlate with global ice volume given by Marine Isotope Stages, and northern hemisphere climatic events (Dortch et al., 2013).

Lee et al. (2014) reconstructed late Quaternary glacial history of the Nun-Kun massif, located on the boundary between the Greater Himalaya and the
Zanskar range in north-western India and identified five glacial stages, namely: (i) the Achambur glacial stage dated to $62.7-38.7 \mathrm{ka}$ (MIS-4 to 3); (ii) the Tongul glacial stage dated to the early part of the Lateglacial (17.4-16.7ka); (iii) the Amantick glacial stage to the later part of the Lateglacial (14.3 ka, 12.4-11.7ka); (iv) the Lomp glacial stage dated to the Little Ice Age; and (v) the Tanak glacial stage probably dating to the last few decades. Given the style and timing of glaciation in the study area, they suggested that climate in the Nun-Kun region is linked to Northern Hemisphere climate oscillations with teleconnections via the mid-latitude westerlies. Moreover, Hedrick et al. (2011) presented glacial chronology for the Puga and Karzok valleys along the south-eastern Zanskar Range. In the Puga valley, glaciers advanced $>15 \mathrm{~km}$ at $\sim 129 \mathrm{ka}$ and $\sim 10 \mathrm{~km}$ at $\sim 46 \mathrm{ka}, \sim 4.2 \mathrm{ka}$ and $\sim 0.6$ ka. In the Karzok valley, glaciers advanced $\sim 1 \mathrm{~km}$ at $\sim 3.6 \mathrm{ka}$. Boulder exposure ages from a large moraine complex in Karzok indicate a glacial advance of $\sim 4$ $\mathrm{km}$ from the present ice margin at $\sim 80 \mathrm{ka}$. The oldest moraine in Karzok, dated to $\sim 311 \mathrm{ka}$, indicated that the glaciers advanced $>10 \mathrm{~km}$ during MIS-9.The chronology of glacial advances in the two valleys shows asynchronicity and absence of early Holocene glaciation and that the pattern of glaciation markedly in these valleys from those in the southern ranges of Lahaul and the Ladakh Range.

In recent studies, Saha et al. (2016) discussed the genesis of streamlined landforms in Yunma and Chandra valley and dated these landforms to $\sim 8-7$ $\mathrm{ka}$, which is evidence of an early Holocene valley glaciation. In addition, they also reported glacial advances during $\sim 17-15$ and $~ 79-52 \mathrm{ka}$ in the middle Yunam valley. Another recent study based on cosmogenic ${ }^{10} \mathrm{Be}$ exposure ages from well-preserved glacially polished surfaces, combined with published data, and an improved production rate scaling model allow reconstruction of the LGM ice extent and subsequent deglaciation in the Chandra valley of NW India (Eugster et al., 2016). They support the view that many Himalayan glaciers advanced during the LGM, likely in response to global variations in temperature.

\section{Monsoon-influenced Himalayan Region}

During the last few years, most of the Quaternary glaciation studies focused in the monsoon dominated 
central Himalaya and provide number of glacial succession ages from this region. For instance, Scherler et al. (2010) based on ${ }^{10} \mathrm{Be}$ dating of lateral and terminal moraines in the upper Tons valley in western Garhwal (Uttarakhand) identified a total of five glacial episodes that occurred after the LGM i.e. $16 \mathrm{ka}$. Following this, four glacial episodes of decreasing magnitude have been dated between $\sim 11$ $12 \mathrm{ka}, \sim 8-9 \mathrm{ka}, \sim 5 \mathrm{ka}$ and $<1 \mathrm{ka}$. The study observed that although there was a significant change in the glacier cover, the ELA was depressed marginally (Scherler et al. 2010). By comparing the glacial chronologies from the western Himalaya with other palaeoclimatic proxy, they suggested that long-term changes in glacial extents are controlled by glacialinterglacial temperature oscillations related to the waxing and waning of the large northern-hemisphere ice sheets, while the timing of millennial-scale advanceand-retreat cycles are more directly related to monsoon strength. Mehta et al. (2014), based on OSL ages, has reported five episodes of glacier advances in the Upper Tons, at $20 \pm 3 \mathrm{ka}, 16 \pm 2 \mathrm{ka}, 8 \pm 1.2 \mathrm{ka}$, $6 \pm 0.7 \mathrm{ka}$ and $3 \pm 0.6 \mathrm{ka}$ and demonstrated a parallelism between the OSL and the TCN of ${ }^{10} \mathrm{Be}$ of Scherler et al. (2010). They suggested that two of the most extensive phases of glaciation were during the early and later parts of MIS-1, which attributed to the lower temperature and enhanced the mid-latitude westerlies. Another study by Mehta et al. (2012), based on moraine stratigraphy supported by OSL dating, identified four major events of glaciations with decreasing magnitude dated to $13 \pm 2 \mathrm{ka}$ (RGS), $9 \pm$ $1 \mathrm{ka}$ (GhGS), $7 \pm 1 \mathrm{ka}$ (GGS) and $5 \pm 1 \mathrm{ka}$ (KGS) in the Chorabari glacier valley (Kedarnath).

Sati et al. (2014) based on optical and radiocarbon dating of lateral moraines in the monsoon dominated Dunagiri valley of the Central Himalaya provide evidence for three major glaciations during the past $\sim 12 \mathrm{ka}$, namely the Bangni Glacial Stage-I (BGS-I) at (12-9 ka, followed by the BGS-II glaciation between 7.5 and $4.5 \mathrm{ka}$ and the BGS-III glaciation at $\sim 1 \mathrm{ka}$. According to the authors, the valley glacier of oldest BGS-I glaciation responded sensitively to decreased temperature and increased precipitation during the early Holocene. The second glacial advance (BGS-II) attributed to low temperatures caused by increased cloudiness and evaporative cooling as suggested by Rupper et al. (2009). A warm and moist climate at $\sim 1 \mathrm{ka}$ was responsible for a reduction in ice volume during the BGS-III glaciation. Moreover, Murari et al. (2014) reported that glacial landforms in central Garwhal are present only within a few kilometres of the present glaciers and all date to less than $\sim 12.5 \mathrm{ka}$. They dated prominent latero-frontal moraines to the Lateglacial, the Early Holocene, and to the Neoglaciation. Accordingly, they suggested that the Lateglacial and/or Holocene glacial advances were more extensive than their predecessors and hence destroyed or buried evidence for earlier glaciation or that other processes, such as intensive fluvial erosion and/or hillslope mass movements, have destroyed evidence of earlier glaciation.

In Goriganga valley, located in the transition zone between the dry steppe of the Tibetan plateau in the north and the sub-humid Himalayan climate in the south, Ali et al. (2013) identified four events of glaciation i.e. Stage-I to IV with decreasing magnitude. The oldest and longest Stage-I glaciation was attributed to the lowered temperature and marginally enhanced ISM and was assigned to MIS-3. The Stage-II optically dated between $\sim 25 \pm 2$ ka and $\sim 22 \pm$ $1 \mathrm{ka}$ which implies significant glacier expansion during the global LGM which is ascribed to a combination of the lowered temperature and enhanced mid-latitude westerlies. The undated younger glacial events viz. Stage-III and IV are speculated to be deposited during the mid-Holocene weak ISM, and the cool and moist Little Ice Age (LIA), respectively. Bali et al. (2013) also observed that glacier significantly advanced during the MIS-3, LGM and mid to late Holocene (6 ka, and $3 \mathrm{ka}$ ) in the Pindari valley. Another recent study from upper Dhauliganga valley, central Himalaya by Bisht et al. (2015) suggested four events of glaciations with decreasing magnitude which are termed as Purvi Kamet Stage-Ia (PKS-Ia), PKS-Ib, PKS-II, PKSIII and PKS-IV respectively. The oldest PKS-Ia and $\mathrm{Ib}$ are assigned the Marine Isotopic Stgae-3 (MIS-3), the PKS-II to the LGM (MIS-2), PKS-III dated to $7.9 \pm 0.7 \mathrm{ka}$ and broadly coincides with the early Holocene cooling event ( $8.2 \mathrm{ka}$ ), and the PKS-IV is dated to $3.4 \pm 0.3 \mathrm{ka}$ and $1.9 \pm 0.2 \mathrm{ka}$ during the late Holocene cool and moist climate. In addition, $\mathrm{Hu}$ et al. (2015) reported most extensive glacial advance in the Basongcuo (BSC) catchment in the eastern Himalayan syntaxis, is consistent with the LGM in monsoon-dominated central and eastern Nepal (Zech et al., 2009; Ali et al., 2013; Owen and Dortch, 2014 and references therein) that started at $\sim 30 \mathrm{ka}$, during 
the late MIS-3, a period of low effective moisture (Herzschuh, 2006) and the beginning of LGM cooling (Thompson et al., 1997). According them, the glacial advances in the BSC catchment were sensitive to global cooling.

\section{Discussion}

In the Himalaya, previous studies suggested strong sensitivity of glaciers to variations in precipitation gradient from eastern Himalaya to the Karakoram ranges in the west and thus to orbitally driven monsoon intensity (Owen and Dortch 2014; Eugster et al. 2016). In the central and eastern Himalaya, it has been suggested that glaciers expanded predominantly during strengthened phases of the ISM with minor advances during weak phases of the ISM (Owen 2009; Dortch et al., 2010b; Owen and Dortch 2014; Sati et al., 2014). While in the western Himalaya westerlies seem to dominate the post LGM glaciations (Dortch et al., 2013; Eugster et al., 2016). Owen et al. (2005) proposed that the glaciers in humid areas advanced due to changes in precipitation, whereas, glaciers in more arid areas are temperature driven and advanced synchronously with northern hemisphere ice sheets. In contrast, Zech et al. (2009) recently suggested that glaciers situated in orographically shielded areas are more sensitive to changes in precipitation; whereas, glaciers that receive high amounts of precipitation are more sensitive to changes in temperature. Rupper et al. (2009) had reported that the increased snow accumulation due to high precipitation, during the mid-Holocene, was much smaller than reductions in ablation caused by lower temperatures attributed to increased cloudiness and evaporative cooling. Thus, despite agreement on the importance of monsoon strength for glacier behavior in the Himalayan realm, the exact mechanisms, timing, and geographic extent of monsoonal influence is debatable (Scherler et al. 2010).

Recent reviews and studies by Dortch et al. (2013), Murari et al. (2014) and Owen and Dortch (2014) have utilized the ${ }^{10} \mathrm{Be}$ TCN dating and have shown a complex pattern with some regions having evidence for glacial advances at times when others show no advance. Despite this complexity, Dortch et al. (2013) examined the glacial successions and ${ }^{10} \mathrm{Be}$ ages across the semi-arid regions at the western end of the Himalayan-Tibetan orogen to develop a regional framework for glaciation across these dryland regions. They recognized nineteen regional glacial stages and named as the semi-arid western Himalayan-Tibetan stages (SWHTS). According them the glacial stages older than $21 \mathrm{ka}$ are correlative with the strong monsoons, whereas, those around 21 ka or younger broadly correlate with global ice volume and northern hemisphere climatic events (Oldest Dryas, Older Dryas, Younger Dryas, Roman Humid Period, and Little Ice Age). Using the methods of Dortch et al. (2013), Murari et al. (2014), with the help of new ${ }^{10} \mathrm{Be}$-ages defined the timing of glaciation in SW Garhwal and recognized 29 regional glacial stages throughout the monsoon-influenced regions of the Himalaya, which they called monsoon-influenced Himalayan-Tibet stages (MOHITS).They suggested that there are strong correlations with both periods of strong monsoons and northern hemisphere events throughout the entire chronologic range. They have identified 16 stages linked to the monsoon and 11 stages linked to the mid-latitude westerlies (two unassigned) with a complex pattern of glaciation influenced by two climatic systems since the mid/late Quaternary. Moreover, Owen and Dortch (2014) by analysing more than $>1700$ ages reported that Himalayan-Tibetan glaciers in arid regions during the last glacial cycle reached their maximum extent early in the cycle and that global LGM glacier advances were significantly less extensive. However, along the more monsoonal-influenced Greater Himalaya, there is increasing evidence to suggest that glaciation was more extensive later in the last glacial cycle and has to be fully assessed (Owen and Dortch 2014).

However, despite a rich collection of $>1700$ cosmogenic exposure ages that mostly stem from moraines (Dortch et al., 2013; Murari et al., 2014; Owen and Dortch, 2014), it has proven difficult to unambiguously identify the nature of the climatic controls on glacier fluctuations during the late Quaternary period. For example, robust data on advances of Himalayan glaciers during the global LGM, defined as the time period of maximum global ice volume from 19 to 23 ka during MIS-2, are limited (Eugster et al., 2016). This particularly applies to the monsoon-influenced sectors of the Himalaya where early last glacial, late glacial, and early Holocene advances are commonly recognized (Sharma and Owen, 1996; Barnard et al., 2004; Owen, 2009; 
Scherler et al., 2010; Ali et al., 2013; Murari et al., 2014; Owen and Dortch, 2014; Sati et al., 2014; Bisht et al., 2015). However, recent studies throughout the Himalayan region including the semi-arid midwesterlies regions e.g. Nubra-Shoyk valley (Nagar et al., 2013), Ladakh region (Dortch et al., 2013), Chandra valley (Eugster et al., 2016) and monsoon dominated regions e.g. Goriganga valley (Ali et al., 2013), Pindari valley (Bali et al., 2013), Tons valley (Mehta et al., 2014; Scherler et al., 2010), upper Dhauliganga valley (Bisht et al., 2015) and Basongcuo (BSC) catchment in the eastern Himalayan syntaxis demonstrate that contrary to the earlier suggestions, a reasonably large valley glacier expansion occurred during the LGM which is ascribed to the eastward penetration of the mid-latitude westerlies.

The another most extensive glacial advance occured during early Holocene in the Himalayan region and particularly also applies to the monsooninfluenced areas. This advance is represented by impressive suites of sharp-crested moraines which have been dated by numerous researchers using radiocarbon, OSL and TCN methods to between $\sim 11.5$ and $8.0 \mathrm{ka}$ (Scherler et al., 2010; Mehta et al., 2012; Murari et al., 2014; Mehta et al., 2014a; Sati et al., 2014; Bisht et al., 2015). However, the extent of glacial advances and ELA depressions during the early Holocene varies considerably between regions. Besides, Glacial advances during the LIA in the Himalayan region are not well defined. However, Dortch et al. (2013) showed that a significant regional glacial stage is recognized across the semi-arid western end of the Himalayan region at $0.4 \pm 0.1 \mathrm{ka}$.

Since the end of the LIA ( 1850s), Himalayan glaciers have been in a general state of recession (Mayewski and Jeschke 1979; Bhambri and Bolch 2009). Himalayan glaciers studies indicate that many glaciers show an increased, receding-trend over the past few decades (Kulkarni et al., 2007; Bolch et al., 2008), and many glaciers have stable fronts since 2000 (Bhambri et al., 2013; Bahuguna et al., 2014). Glaciers in the Karakoram region, show long-term irregular behavior with frequent advances and possible slight mass gain since 2000 (Hewitt 2011; Bolch et al., 2012; Kääb et al., 2012; Gardelle et al., 2013; Bhambri et al., 2013). For instance, on the basis of SoI topographic maps and Indian remote sensing satellite (IRS) images, Kulkarni (2012) estimated glaciers of Bhut basin retreat from 1962 to 2001 in the Jammu and Kashmir (J\&K) Himalaya at $10 \%$ $\left(\sim 0.3 \% \mathrm{a}^{-1}\right)$, retreat in Warwan basin at $21 \%(\sim 0.6 \%$ $\left.\mathrm{a}^{-1}\right)$ and retreat in Zanskar at $9 \%\left(\sim 0.3 \% \mathrm{a}^{-1}\right)$. In the Himachal Himalaya, Kulkarni et al. (2007) reported a glacier retreat rate of $21 \%\left(\sim 0.5 \% \mathrm{a}^{-1}\right)$ in Chenab basin, $22 \%\left(\sim 0.6 \% \mathrm{a}^{-1}\right)$ in Parbati, a sub-basin of Beas and $19 \%\left(\sim 0.5 \% \mathrm{a}^{-1}\right)$ in Baspa, a sub-basin of Sutlej. In addition, there were noticeable variations within sub-basins of Chenab as glaciers in the Bhaga, subbasin of Chenab, retreated at $30 \%\left(\sim 0.8 \mathrm{a}^{-1}\right)$ whereas in the adjoining sub-basin of Chandra and Miyar (for 111 glaciers $)$, glaciers retreats were $20 \%\left(0.5 \mathrm{a}^{-1}\right)$ and $8 \%\left(0.2 \mathrm{a}^{-1}\right)$, respectively, from 1962 to 2001/ 2004 (Kulkarni, 2012) based on the Survey of India (SoI) topography map and LISS III images (spatial resolution $23.5 \mathrm{~m}$ ). Mir et al. (2013) reported a noticeable deglaciation of $26.1 \%\left(\sim 0.6 \mathrm{a}^{-1}\right)$ for the mapped 34 glaciers in Tirungkhad sub-basin of Sutlej during 1966-2011 using the SoI toposheets and Landsat satellite images. However, Pandey and Venkataraman (2013) reported a comparatively lower retreat rate of $2.5 \%\left(\sim 0.1 \mathrm{a}^{-1}\right)$ for the 15 glaciers in Chandra and Bhaga sub-basins of Chenab (19802010) using the remote sensing datasets of Landsat MSS/TM and IRS LISS-III/AWFIS. Morever, the recent study by (Chand and Sharma (2015) also reported lower recession rate of $4.6 \pm 4.1 \%$ for Ravi basin glaciers of Himachal Himlaya using high to medium resolution datasets of Corona, WorldView-2 and Landsat 8 OLI/TRIS. In addition, Bhambri et al. (2011) estimated comparatively less glacier loss at $4.6 \pm 2.8 \%\left(\sim 0.1 \pm 0.1 \% \mathrm{a}^{-1}\right)$ based on high resolution Corona and Cartosat-1 imageries from 1968 to 2006 in the Bhagirathi and Saraswati/Alaknanda basin of Garhwal Himalaya which is similar to Chand and Sharma (2015) $\left(0.1 \pm 0.1 \% \mathrm{a}^{-1}\right)$. For the Sikkim Himalaya, Basnett et al. (2013) reported the glaciers loss as an area of $3.3 \pm 0.8 \%\left(\sim 0.2 \pm 0.1 \% \mathrm{a}^{-1}\right)$ between $1989 / 90$ and 2010 . In contrast, there was heterogeneity found in glacier response in Karakoram region. For example, based on space imagery, Bhambri et al. (2013) reported an overall slight area gain of $0.1 \pm 3.5 \%$ for the glaciers in the upper Shyok valley from 1973 to 2011. This suggests that the Karakoram area is showing a different response to climate change than other parts of the Himalaya.

The long term rate of retreat for the past four decades is available for around 100 glaciers in the 
Himalaya (Kulkarni and Karyakarte 2014; Bolch et $a l ., 2012)$. The reported mean loss of glacial length over four decades is approximately $621 \pm 468 \mathrm{~m}$, with large variations across the Himalayan region (Kulkarni and Karyakarte 2014). Morover, the recent studies on individual glaciers also suggest that most of the glaciers are in retreating phase although the rate of retreat varies from one glacier to another (Mehta et al., 2011; Azam et al., 2012; Bhambri et al., 2012; Pandey and Ghosh 2012; Dobhal et al., 2013; Mehta et al., 2013; Pandey and Venkataraman 2013; Mehta et al., 2014b; Azam et al., 2014; Chand and Sharma 2015b; Chand et al., 2016; Nainwal et al., 2016; Chand and Sharma 2016). Such complexity and variations invites a rigorous and systematic analysis of the Himalayan glaciers instead of direct comparisons and extrapolations of results from wellstudied glaciers in some of the basin to others poorly observed glacierized basin (Chand and Sharma 2015a). Besides, the earlier studies on the estimation of glacial area and recession for the Indian Himalaya are based on SoI maps (1960s-70s) and coarserresolution satellite images (Kulkarni et al., 2007; Mehta et al., 2011; Pandey et al., 2011; Mir et al., 2013; Mehta et al., 2013; Pandey and Venkataraman 2013; Mehta et al., 2014b). However, the recent studies suggests that earlier estimations primarily based on SoI maps are highly erroneous and overestimate glacial change, and therefore reassessment and recalculation based on high reolustion images, if possible, are required for more accurate and pragmatic results (Chand and Sharma 2015b; Chand and Sharma 2015a; Chand et al., 2016). Moreover, the irregular behavior of Himalayan glaciers fluctuation in general could be attributed to local/ regional topography (Haeberli 1990), local/regional climatic system (Kargel et al., 2005), glacier hypsometry (Furbish and Andrews 1984), the characteristics and thickness of supraglacial debris cover on the glacier surface (Bolch et al., 2008; Scherler et al., 2011; Chand and Sharma 2015a), the glacier size and ratio of accumulation area to total area (Kulkarni et al., 2007), contributions from tributary glaciers (Nainwal et al., 2008) and their geometrical/morphological properties (Mehta et al., 2014b). In addition, increased deposition of black carbon on glaciers and reported climate warming across the Himalayan region, is supposed to enhance melting (Menon et al., 2010; Gertler et al., 2016).
Moreover, in monsoon-influenced regions, predicted increased snowfall and increased cloudiness may lead to positive glacier mass balances. Consequently, some glaciers may thicken and advance and it needs exhaustive research (Owen and Dortch, 2014).

\section{Conclusion}

In recent years, number of studies has been carried out to understand the nature, timing, and extent of Late Quaternary glaciation in the Himalayan region specifically aided by improvements in remote sensing and dating methods. There has been 22 studies carried out on Himalayan Quaternary glaciation during the past six years (2010-2016) with equal contribution from India counterpart in terms of total output. Most of these studies are concentrate in the north-western Himalaya with few studies from eastern part. Recently published new glacial succession chronology $\left({ }^{10} \mathrm{Be}\right.$, OSL, ESR and ${ }^{14} \mathrm{C}$ ) suggest complex patterns of glaciation that are emerging imply that glaciation throughout the Himalayan region reflects temporal and spatial variability of forcing by the different climatic systems that dominate the region. Moreover, it shows that throughout most Himalayan regions, significant glacier advances occurred during Last glacial and early Holocene, with minor advances in some regions during the mid-Holocene. However, recent study in the throughtout Himlayan region demonstrate that contrary to the earlier suggestions, a reasonably large valley glacier expansion occurred during the global LGM, likely in response to global variations in temperature.

Moreover, there is a growing concern to comprehend the pattern of deglaciation following the LIA is important for understanding the role of natural versus anthropogenic contribution in glaciers response, particularly considering significant debate pertaining to the rising global temperature and its likely impact on the mountain glaciers (IPCC 2007, 2013). However, the pattern of glacial dynamics is complex and asynchronous during the climatostratigraphic times including recent period. Thus in view of the studies, to draw a conclusion, it is important to map glacial succession in different climate zones, especially for those poorly investigated areas of the Himalaya e.g. Eastern Himalaya field record and supplemented with high resolution remote sensing datasets in order to examine the interlinkages between climatic, non- 
climatic and glacial systems in implication to regional water balance, recharge of river-fed aquifers and hydrological regime for hydro-power, agriculture, ecosystems of the high altitude and foreland areas in the densely populated spaces of South Asia.

\section{References}

Ali S N, Biswas R H, Shukla A D and Juyal N (2013) Chronology and climatic implications of Late Quaternary glaciations in the Goriganga valley, central Himalaya, India Quat Sci Rev 73 59-76 doi: 10.1016/j.quascirev.2013.05.016

Ali S N and Juyal N (2013) Chronology of late quaternary glaciations in Indian Himalaya: A critical review J Geol Soc India 82 628-638 doi: 10.1007/s12594-013-0201-9

Andersen K K, Azuma N, Barnola J-M et al. (2004) Highresolution record of Northern Hemisphere climate extending into the last interglacial period Nature 431 147-151

Azam M F, Wagnon P, Ramanathan A et al. (2012) From balance to imbalance: a shift in the dynamic behaviour of Chhota Shigri glacier, western Himalaya, India J Glaciol 58315 324 doi: 10.3189/2012JoG11J123

Azam M F, Wagnon P, Vincent C et al. (2014) Reconstruction of the annual mass balance of Chhota Shigri glacier, Western Himalaya, India, since 1969 Ann Glaciol 55 69-80 doi: 10.3189/2014AoG66A104

Bahuguna I M, Rathore B P, Brahmbhatt R et al. (2014) Are the Himalayan glaciers retreating? Curr Sci 106 1008-1013

Bali R, Nawaz Ali S, Agarwal K K et al. (2013) Chronology of late Quaternary glaciation in the Pindar valley, Alaknanda basin, Central Himalaya (India) J Asian Earth Sci 66 224233 doi: 10.1016/j.jseaes.2013.01.011

Barnard P L, Owen LA, Sharma M C and Finkel R C (2004) Late Quaternary (Holocene) landscape evolution of a monsooninfluenced high Himalayan valley, Gori Ganga, Nanda Devi, NE Garhwal Geomorphology 61 91-110 doi: 10.1016/ j.geomorph.2003.12.002

Benn D I and Owen L A (1998) The role of the Indian summer monsoon and the mid-latitude westerlies in Himalayan glaciation: Review and speculative discussion J Geol Soc London 155 353-363

Bhambri R and Bolch T (2009) Glacier mapping: a review with special reference to the Indian Himalayas Prog Phys Geogr 33 672-704 doi: 10.1177/0309133309348112

Bhambri R, Bolch T and Chaujar R K (2012) Frontal recession of

\section{Acknowledgments}

Sincere thanks to Prof. Ashok Kumar Singhvi for encouraging us to write this paper and being patient with our submission time. Many thanks to anonymous reviewers for constructive comments that helped us to improve our manuscript.

Gangotri Glacier, Garhwal Himalayas, from 1965 to 2006, measured through high-resolution remote sensing data $\mathrm{Curr}$ Sci 102 1462-1466

Bhambri R, Bolch T, Kawishwar P et al. (2013) Heterogeneity in glacier response in the upper Shyok valley, northeast Karakoram Cryosph 7 1385-1398 doi: 10.5194/tc-7-13852013

Bisht P, Ali S N, Shukla A D et al (2015) Chronology of late Quaternary glaciation and landform evolution in the upper Dhauliganga valley, (Trans Himalaya), Uttarakhand, India Quat Sci Rev 129 147-162 doi: 10.1016/j.quascirev.2015. 10.017

Bolch T, Buchroithner M, Pieczonka T and Kunert A (2008) Planimetric and volumetric glacier changes in the Khumbu Himal, Nepal, since 1962 using Corona, Landsat TM and ASTER data $J$ Glaciol 54 592-600 doi: 10.3189/ 002214308786570782

Bolch T, Kulkarni A, Kääb A et al. (2012) The state and fate of Himalayan glaciers Science 336 310-4 doi: 10.1126/ science. 1215828

Bookhagen B and Burbank D W (2006) Topography, relief, and TRMM-derived rainfall variations along the Himalaya 33 1-5 doi: 10.1029/2006GL026037

Brozovic N, Burbank D W and Meigs A J (1997) Climatic Limits on Landscape Development in the Northwestern Himalaya Science 276 571-574 doi: 10.1126/science.276.5312.571

Chand P and Sharma M C (2015a) Glacier changes in the Ravi basin, north-western Himalaya (India) during the last four decades (1971-2010/13) Glob Planet Change 135 133147 doi: 10.1016/j.gloplacha.2015.10.013

Chand P and Sharma M C (2015b) Frontal changes in the Manimahesh and Tal Glaciers in the Ravi basin, Himachal Pradesh, northwestern Himalaya (India), between 1971 and 2013 Int J Remote Sens 36 4095-4113

Chand P and Sharma M C (2016) Monitoring Frontal Changes of Shah Glacier in the Ravi Basin, Himachal Himalaya (India) from 1965 to 2013 Natl Acad Sci Lett 39 109-114 doi: 10.1007/s40009-016-0420-x 
Chand P, Sharma M C and Prasad R N (2016) Heterogeneity in Fluctuations of Glacier with Clean Ice-Covered, DebrisCovered and Proglacial Lake in the Upper Ravi Basin, Himachal Himalaya (India), During the Past Four Decades (1971-2013). Climate Change, Glacier Response, and Vegetation Dynamics in the Himalaya. Springer International Publishing, Cham, pp 155-179

Dobhal D P, Mehta M and Srivastava D (2013) Influence of debris cover on terminus retreat and mass changes of Chorabari Glacier, Garhwal region, central Himalaya India J Glaciol 59 961-971

Dortch J M, Owen L A and Caffee M W (2013) Timing and climatic drivers for glaciation across semi-arid western Himalayan-Tibetan orogen Quat Sci Rev 78 188-208 doi: 10.1016/j.quascirev.2013.07.025

Dortch J M, Owen L A and Caffee M W (2010a) Quaternary glaciation in the Nubra and Shyok valley confluence, northernmost Ladakh, India Quat Res 74 132-144 doi: 10.1016/j.yqres.2010.04.013

Dortch J M, Owen L A, Caffee M W and Brease P (2010b) Late Quaternary glaciation and equilibrium line altitude variations of the McKinley River region, central Alaska Range doi: 10.1111/j.1502-3885.2009.00121.x

Eugster P, Scherler D, Thiede R C et al. (2016) Rapid Last Glacial Maximum deglaciation in the Indian Himalaya coeval with midlatitude glaciers: New insights from ${ }^{10} \mathrm{Be}$-dating of icepolished bedrock surfaces in the Chandra Valley, NW Himalaya Geophys Res Lett 43 1589-1597 doi: 10.1002/ 2015GL066077

Furbish J D and Andrews J T (1984) The use of hypsometry to indicate long-term stability and response of valley glaciers to changes in mass transfer J Glaciol 30 199-211

Gardelle J, Berthier E, Arnaud Y and Kääb A (2013) Region-wide glacier mass balances over the Pamir-Karakoram-Himalaya during 1999-2011 Cryosph 7 1263-1286 doi: 10.5194/tc7-1263-2013

Gertler C G, Puppala S P, Panday A et al. (2016) Black carbon and the Himalayan cryosphere: A review Atmos Environ 125 404-417

Gillespie A and Molnar P (1995) Asynchronous maximum advances of mountain and continental glaciers Rev Geophys 33311 doi: 10.1029/95RG00995

Haeberli W (1990) Glacier and permafrost signals of 20th-century warming Ann Glaciol 4 99-101

Hedrick KA, Seong Y B, Owen LA et al. (2011) Towards defining the transition in style and timing of Quaternary glaciation between the monsoon-influenced Greater Himalaya and the semi-arid Transhimalaya of Northern India Quat Int
236 21-33 doi: 10.1016/j.quaint.2010.07.023

Herzschuh U (2006) Palaeo-moisture evolution in monsoonal Central Asia during the last 50,000 years Quat Sci Rev 25 163-178 doi: 10.1016/j.quascirev.2005.02.006

Hewitt K (2011) Glacier Change, Concentration, and Elevation Effects in the Karakoram Himalaya, Upper Indus Basin Mt Res Dev 31 188-200 doi: 10.1659/MRD-JOURNALD-11-00020.1

Hu G, Yi C L, Zhang J F et al. (2015) Luminescence dating of glacial deposits near the eastern Himalayan syntaxis using different grain-size fractions Quat Sci Rev 124 124-144

IPCC Working Group 1, Stocker T F, Qin D et al. (2013) Climate Change 2013: The Physical Science Basis. Contribution of Working Group I to the Fifth Assessment Report of the Intergovernmental Panel on Climate Change.

IPCC IPCC (2007) IPCC, 2007: Summary for Policymakers.

Kääb A, Berthier E, Nuth C et al. (2012) Contrasting patterns of early twenty-first-century glacier mass change in the Himalayas Nature 488 495-8 doi: 10.1038/nature11324

Kargel J S, Abrams M J, Bishop M P et al. (2005) Multispectral imaging contributions to global land ice measurements from space Remote Sens Environ 99 187-219 doi: 10.1016/ j.rse.2005.07.004

Kulkarni A V (2012) Monitoring Himalayan cryosphere using remote sensing techniques J Indian Inst Sci 90 457-469

Kulkarni A V, Bahuguna I M, Rathore B P et al. (2007) Glacial retreat in Himalaya using Indian Remote Sensing satellite data Curr Sci 92 69-74

Lee S Y, Seong Y B, Owen L A et al. (2014) Late Quaternary glaciation in the Nun-Kun massif, northwestern India Boreas 43 67-89 doi: 10.1111/bor.12022

Leuschner D C and Sirocko F (2003) Orbital insolation forcing of the Indian Monsoon - A motor for global climate changes? Palaeogeogr Palaeoclimatol Palaeoecol 197 83-95

Mayewski P A and Jeschke P A (1979) Himalayan and TransHimalayan Glacier Fluctuations Since AD 1812 Arct Alp Res 11 267-287

Mehta M, Dobhal D, Pratap B et al. (2014a) Late Quaternary glacial advances in the Tons River Valley, Garhwal Himalaya, India and regional synchronicity The Holocene 24 1336-1350 doi: 10.1177/0959683614540947

Mehta M, Dobhal D P and Bisht M P S (2011) Change of Tipra Glacier in the Garhwal Himalaya, India, between 1962 and 2008 Prog Phys Geogr 35 721-738 doi: 10.1177/ 0309133311411760

Mehta M, Dobhal D P, Kesarwani K et al. (2014b) Monitoring of glacier changes and response time in Chorabari Glacier, 
Central Himalaya, Garhwal, India Curr Sci 107 281-289

Mehta M, Dobhal D P, Pratap B et al. (2013) Glacier changes in Upper Tons River basin, Garhwal Himalaya, Uttarakhand, India Zeitschrift für Geomorphol 57 225-244 doi: 10.1127/ 0372-8854/2012/0095

Mehta M, Majeed Z, Dobhal D P and Srivastava P (2012) Geomorphological evidences of post-LGM glacial advancements in the Himalaya: A study from Chorabari Glacier, Garhwal Himalaya, India J Earth Syst Sci 121 149-163 doi: 10.1007/s12040-012-0155-0

Menon S, Koch D, Beig G et al. (2010) Black carbon aerosols and the third polar ice cap Atmos Chem Phys 10 4559-4571 doi: 10.5194/acp-10-4559-2010

Mir R A, Jain S K, Saraf A K and Goswami A (2013) Glacier changes using satellite data and effect of climate in Tirungkhad basin located in western Himalaya Geocarto Int 29 293-313 doi: 10.1080/10106049.2012.760655

Molnar P and England P (1990) Late Cenozoic uplift of mountain ranges and global climate change: chicken or egg? Nature 346 29-34 doi: 10.1038/346029a0

Murari M K, Owen L A, Dortch J M et al. (2014) Timing and climatic drivers for glaciation across monsoon-influenced regions of the Himalayan-Tibetan orogen Quat Sci Rev $\mathbf{8 8}$ 159-182 doi: 10.1016/j.quascirev.2014.01.013

Nagar Y C, Ganju A, Satyawali P K and Juyal N (2013) Preliminary optical chronology suggests significant advance in Nubra valley glaciers during the Last Glacial Maximum Curr Sci 105 96-101

Nainwal H C, Banerjee A, Shankar R et al. (2016) Shrinkage of Satopanth and Bhagirath Kharak Glaciers, India, from 1936 to 2013 Ann Glaciol 57 131-139

Nainwal H C, Negi B D S, Chaudhary M et al. (2008) Temporal changes in rate of recession: Evidences from Satopanth and Bhagirath Kharak glaciers, Uttarakhand, using Total Station Survey Curr Sci 94 653-660

Norton K P, Abbühl L M and Schlunegger F (2010) Glacial conditioning as an erosional driving force in the Central Alps Geology 38 655-658 doi: 10.1130/G31102.1

Owen L A (2009) Latest Pleistocene and Holocene glacier fluctuations in the Himalaya and Tibet Quat Sci Rev $\mathbf{2 8}$ 2150-2164 doi: 10.1016/j.quascirev.2008.10.020

Owen L A, Caffee M W, Finkel R C and Seong Y B A E (2008) Quaternary glaciation of the Himalayan - Tibetan orogen 23 513-531 doi: 10.1002/jqs

Owen LA and Dortch J M (2014) Nature and timing of Quaternary glaciation in the Himalayan-Tibetan orogen Quat Sci Rev 88 14-54 doi: 10.1016/j.quascirev.2013.11.016
Owen L A, Finkel R C and Caffee M W (2002) A note on the extent of glaciation throughout the Himalaya during the global Last Glacial Maximum Quat Sci Rev 21 147-157 doi: 10.1016/S0277-3791(01)00104-4

Pandey A C and Ghosh S (2012) Area Change and Thickness Variation over Pensilungpa Glacier ( $\mathrm{J} \& \mathrm{~K}$ ) using Remote Sensing 40 245-255 doi: 10.1007/s12524-011-0134-y

Pandey A C, Ghosh S, Nathawat M S and Tiwari R K (2011) Area Change and Thickness Variation over Pensilungpa Glacier (J\&K) using Remote Sensing J Indian Soc Remote Sens 40 245-255 doi: 10.1007/s12524-011-0134-y

Pandey P and Venkataraman G (2013) Changes in the glaciers of Chandra-Bhaga basin, Himachal Himalaya, India, between 1980 and 2010 measured using remote sensing Int J Remote Sens 34 5584-5597 doi: 10.1080/01431161.2013.793464

Prell W L and Kutzbach J E (1992) Sensitivity of the Indian monsoon to forcing parameters and implications for its evolution Nature $\mathbf{3 6 0}$ 647-652

Raymo M E and Ruddiman W F (1992) Tectonic forcing of late Cenozoic climate Nature 359 117-122

Ruddiman W F and Kutzbach J E (1991) Plateau uplift and climatic-change Sci Am 264 66-75

Rupper S, Roe G and Gillespie A (2009) Spatial patterns of Holocene glacier advance and retreat in Central Asia Quat Res 72 337-346 doi: 10.1016/j.yqres.2009.03.007

Saha S, Sharma M C, Murari M K et al. (2016) Geomorphology, sedimentology and minimum exposure ages of streamlined subglacial landforms in the NW Himalaya, India Boreas 45 284-303

Sati S P, Ali S N, Rana N et al. (2014) Timing and extent of Holocene glaciations in the monsoon dominated Dunagiri valley (Bangni glacier), Central Himalaya, India J Asian Earth Sci 91 125-136 doi: 10.1016/j.jseaes.2014.05.008

Scherler D (2010) Climate variability and glacial dynamics in the Himalaya. University of Postdam

Scherler D, Bookhagen B and Strecker M R (2011) Spatially variable response of Himalayan glaciers to climate change affected by debris cover Nat Geosci 4 156-159 doi: 10.1038/ ngeo1068

Scherler D, Bookhagen B, Strecker M R et al. (2010) Timing and extent of late Quaternary glaciation in the western Himalaya constrained by $10 \mathrm{Be}$ moraine dating in Garhwal, India Quat Sci Rev 29 815-831 doi: 10.1016/ j.quascirev.2009.11.031

Sharma M and Owen L A (1996) Quaternary glacial history of NW Garhwal, Central himalayas Quat Sci Rev 15 335-365 doi: 10.1016/0277-3791(95)00061-5 
Thompson L G, Yao T, Davis M E et al. (1997) Tropical Climate Instability: The Last Glacial Cycle from a Qinghai-Tibetan Ice Core Science 276 1821-1825 doi: 10.1126/ science. 276.5320 .1821

Willett S D (2010) Erosion on a line Tectonophysics 484 168-180 doi: 10.1016/j.tecto.2009.09.011
Yang B, Bräuning A, Dong Z et al. (2008) Late Holocene monsoonal temperate glacier fluctuations on the Tibetan Plateau Glob Planet Change 60 126-140 doi: 10.1016/j.gloplacha. 2006.07.035

Zeitler P K, Meltzer A S, Koons P O et al. (2001) Erosion, Himalayan geodynamics, and the geomorphology of metamorphism GSA Today 11 4-9 doi: 10.1130/10525173(2001)011\%3C0004:EHGATG\%3E2.0.CO;2. 